\title{
POLARIZAÇÃO GEOELÉTRICA DE MODELOS LAMINARES EM MEIOS COM DUAS CAMADAS: UM ESTUDO POR CORRENTES DE FACE
}

\author{
Rodinei Antonio Pachani \\ Orientador: Dr. Carlos Alberto Mendonça (IAG-USP) \\ 56 p - Dissertação (Mestrado) - Defesa 06.02.2004
}

RESUMO. Métodos elétricos do tipo ativo produzem imagens do substrato terrestre a partir do processamento do potencial elétrico que se estabelece em resposta à injeção de corrente contínua no meio. A intensidade do potencial medido na superfície do terreno depende do grau de polarização imposto aos alvos no substrato. A técnica das correntes de face permite inferir o grau de polarização experimentado por uma estrutura e, com isso, identificar situações favoráveis à aplicação da investigação geoelétrica. Essa técnica, entretanto, assume que as feições de interesse estejam inseridas num semi-espaço homogêneo. A presente pesquisa estende a formulação por correntes de face para meios compostos por duas camadas. A base matemática gerada permite estudar modelos mais representativos da exploração mineral e de água subterrânea e estudos de contaminação ambiental. Os resultados obtidos na análise de modelos laminares mostram que a polarização destas feições é condicionada por seu contraste de condutividade e que 0 efeito de canalização de corrente desempenha papel secundário. Para feições muito rasas 0 grau de polarização praticamente não depende do modelo para o meio de fundo. Padrões mais complexos de polarização são inferidos para estruturas que atravessam meios com condutividades distintas. Neste caso, uma mesma estrutura pode ficar polarizada por correntes negativas e positivas, dependendo do contraste de condutividade em relação ao meio de fundo.

ABSTRACT. Active electrical methods produce images for the Earth subsurface by processing the electrical potential established on the ground surface in response to a direct current source. The intensity of the potential measured on the ground surface depends on the polarization degree imposed to the underground targets. The face current technique allows inferring the structure polarization degree and, with this, the identification of favorable conditions to conduct a geoelectrical exploration. This technique, however, assumes that searched features are embedded into a homogeneous half space. The presented research extends the face current formulation for background media composed by two homogeneous layers. The derived mathematical solutions allow studying more representative models that commonly are used in mineral and groundwater exploration, and characterization of contaminated sites. The results from analyzing thin sheet models reveal that sheet polarization mainly is conditioned by its conductivity contrast. For shallower features, the polarization degree is almost invariant with the background model. More complex patterns of polarization are expected from targets within media with two resistivity values. In this case, positive and negative face currents may simultaneously polarize the same structure, depending on target conductivity contrast with respect to the background medium. 